\title{
The Effect of Jussiaea Octovalvis Weed Densities on the Growth and Yield of Several Introduced Vietnam Rice (Oryza Sativa) Varieties
}

\author{
Tu Ngoc Phan Thi ${ }^{a}$, Ardi $^{b}$, Warnita ${ }^{c}$ \\ a Faculty of Agriculture, Andalas University, Padang, West Sumatra, Indonesia \\ b Faculty of Agriculture, Andalas University, Padang, West Sumatra, Indonesia \\ c Faculty of Agriculture, Andalas University, Padang, West Sumatra, Indonesia
}

\section{ARTICLE INFORMATION}

\section{Article history:}

Received:

Revised:

Accepted:

Keywords:

Jeussiaa octovalvis weed, rice growth, rice yield, weed densities, weed effect

\section{Correspondence:}

phanthingoctu1994@outlook.com

\section{A B S T R A C T}

Rice is staple grain production that plays an important role in food security and the socio-economic value of agriculture in South East Asia countries. Among the factors that have negative effects on rice, weed is the major one. Its production constraint is directly seeded rice; besides, weed also affects rice growth and yield by competition about light, water, nutrient, space. Jussiaea octovalvis is a kind of weed in the field during rice growth to mature, which affects the growth and yield of rice but not significantly different based on this research. Treatments were arranged factorially in Randomized Block Design (RCBD) with two factors, 20 treatments (4 varieties, 5 of weed densities), and four replications, and each repetition used two pots for each treatment. As a result, the data showed the difference between the rate of growth and the yield of rice grain recovery products. Especially at data of LL 58 DAP showed significant difference $(\mathrm{P}=0.017)$, which the highest rate is 59.13 $\mathrm{cm}$ of V2; for harvest data showed that V3 is the best result, but it is also a sensitive one in the condition of weed densities impaction more than the others varieties (D0V3=620.5; D4V3=438). Besides, the measurement of W1000 of rice grain $(30.96 \mathrm{~g})$ and $\mathrm{Wt}$ per pot (20.01 g) of D0V3 is weight more than the other treatment; within D4V4 was obtained lowest of W1000 (19.26 g) and the lowest of Wt is D1V1 (5.25 g). Besides that, D2 and D4 are more effective on rice growth and yield, and it was non-significant. However, it is not the interaction between weed densities and varieties of rice. 


\section{INTRODUCTION}

Rice (Oryza sativa) is among the three most important grain crops in the world, and it has a major contributrion to fulfill the food needs across the globe (Chauhan, Jabran, \& Mahajan, 2017). In Viet Nam, rice is also important food and to export out the world. According to (Quang , 2017), Viet Nam is a country which the cultivated surface of rice is the sixth in the world with rice producing is 77.6 million ha and export rice out the world that value is achieved 2 billion USD every years. In 2017, follow Ministry of Industry and Trade example that year were successful of year of producing rice in Viet Nam with 5.52 million ton equivalent 2.49 billion USD (Quang, 2017). Specially, Mekong Delta religion where is the largest of rice production in the Southern of Vietnam; which the most produce of varieties rice is routine planting such as OM 5451, OM 4900, Jasmine, OM6976, OM 9677, ect; these kind of varieties are famous with the high yield.

Beside that, Indonesia is the importer rice from others country and rice also is politically strategic commodity in Indonesia and the government seeks to ensure that rice production most the needs if domestic consumption is accordingly is interested for its performance in accordingly for its performance and in accordance with several determining factors. The estimates of the 2017 harvest in Indonesia have been lowered by 330.000 tons to 7.9 millions tons (Food and Agriculture Origanization of The United Nations (FAO), 2018). However, in recent years total rice consumption has been rising faster than production, as the growth rate of national rice areas and yield has flattered. Thus, these increases would more than compensate for cuts in other traditional importers, namely in Indonesia (Food and Agriculture Origanization of The United Nations (FAO), 2018). Productivity is related to be finding now high fielding rice varieties that potentially increase the yield per ha, stabilizing rice field by better management to prevent or to control pest and disease incidence, and post harvested; also the varieties rice. The efficiency of those methods for increasing rice production differ from one region to another region which this depends on the natural also social-economic conditions and also depend on which the kind of varieties; which the regularly of varieties (Indonesia) use such as Cisoka, IR - 64, Cre kuning, Cere unggul, ect.

There is improvement of rice yield we need to control the weed. And weed is as old as agriculture, from the very beginning farmers realized that the weed interference with crop production (Ghersa, BenechArnold, Satorre, \& Martinez-Ghersa, 2000). Following (Chauhan \& Johson, Growth Reponse of Direct Seeded Rice to Oxadiazon and Bispyribac-Sodium in Aerobic and Saturated Soils, 2011), weeds are the greatest yieldlimiting constraint to rice. The reason why weed make rice yield loss cause weeds compete with rice plants severely for space, nutrients, air, water and light and thus adversely affecting growth and yield of rice (Singh et al., 2007). In the other hand, weed population, period of weed competition, relative time of crop and weed emergence, crop and parts harvested, and growth habit and vigor of the weed effect losses caused by weed. From the others researcher, (Ramzan, 2003) showed in his study that weed could reduce rice yield up to 48,53 and $74 \%$ in transplanted, direct seeded flooded and direct seeded, respectively. Beside that in tropical area, the average of rice yield losses from weeds is $35 \%$ (Oerke \& Dehne, 2004). (Sunil, Shekara, Kalyanmurthy, \& Sha nkaralingapa, 2010) research showed that season-long weed competition in rice cause of yield reduction up to $80 \%$. On the other hand, reported from (Jayadeva, et al., 2011) that complete failure of crops due to weeds in rice. However, effect of weeding regime on growth and yield performance of rice depends on many factors including growing season, weed pressure, competitiveness of variety, planting density, agronomic management and so on (Juraimi, Uddin, Anwar, Mohamed, Ismail, \& Man, 2013).

Generally, weed competition during the early growing season usually depresses crop growth more than competition at other times such as Monochoria vaginalis, Cyperaceae, Echinochloa Colona (L.), Leptochloa chinensis, Jussiaea linitotia, Echinochloa crus-galli, Cyperus difformis, Jussiaea octovalvis (the other name Ludwigia octovalvis), ect.

Ludwigia octovalvis octovalvis is a primary weed in the rice field, were found in lowland; it is the willowherb familly (Onagraceae) and also is perennials weed (Naidu, 2012); it is widespread in Asia and Jussiaea octovalvis is found throughout the Tropics from sea level to $1500 \mathrm{~m}$ elevation (Cabi, Invasive Species Compendium, 2019). That also has high competitiveness with crop most commonly in either rainfed or irrigated rice fields (Caton, Mortimer, Hill, \& Johnson, 2010). The study from (Dharmaratne \& Ranamukaarachchi, 1991), which the result about the average height of rice varied from 48.1 to $49.4 \mathrm{~cm}$ and increased density of Ludwigia did not affect the height of rice during Maha. However, during Yala, the height of rice increased with increasing Ludwigia densities up to 16 plants $/ \mathrm{m}^{2}$ (Dharmaratne \& Ranamukaarachchi, 1991).

In the view of the above opinion, the study was undertaken to find out how Jussiaea octovalvis weeding - is a one kind of weed which usually appear in paddy field - effect on growth and yield of several introduce varieties rice from Vietnam and compare with local rice in Padang, Indonesia. 


\section{MATERIALS AND METHODS}

\section{Study area, sampling}

The study was conducted at Greenhouse at Andalas University and treatments were arranged factorially in weed. Specially, for harvest data it was taken different time between different varieties because of growing time of each variety is different.

The study was using Excel, SPSS and Minitab software for analyzing data. Using comparative method of

Table 2. The interaction between WD and varieties rice which affect on number of leaf 72 DAP. Which is D0= non-weed, D1 = one weed, D2= Two weeds, D3= three weeds, D4= four weeds.

\begin{tabular}{llllll}
\hline \multirow{2}{*}{ Varieties } & \multicolumn{5}{c}{ Weed densities per pot } \\
\cline { 2 - 5 } & Non-weed & One weed & Two weeds & Three weeds & Four weeds \\
\hline OM 5451 & $14.35 \mathrm{aB}$ & $13 \mathrm{aB}$ & $13 \mathrm{aB}$ & $15.13 \mathrm{aB}$ & $14.88 \mathrm{aB}$ \\
OM 4900 & $16.88 \mathrm{aB}$ & $14.38 \mathrm{aB}$ & $14.38 \mathrm{aB}$ & $16.6 \mathrm{aB}$ & $14.75 \mathrm{aB}$ \\
Jasmine & $24.5 \mathrm{Aa}$ & $21.63 \mathrm{Aa}$ & $21.63 \mathrm{Aa}$ & $16.88 \mathrm{Aa}$ & $18.13 \mathrm{Aa}$ \\
Cisokan & $19.25 \mathrm{Aa}$ & $16.85 \mathrm{Aa}$ & $16.85 \mathrm{Aa}$ & $21.38 \mathrm{Aa}$ & $15.5 \mathrm{Aa}$ \\
\hline
\end{tabular}

Randomized Blosike Design (RBD) with 2 factors, 20 variance (ANOVA) and Tukey (Post-hoc) for treatments (4 varieties - OM 5451=V1; OM 4900=V2; comparing which is significant difference between Jasmine $=\mathrm{V} 3$ and $\mathrm{Cl}$ (80kan=V4, 5 of 3 keed densities non weed=D0; one weed=D1; two weeds=D2; three weeds=D3 and four weeds=D4) and 4 replications, each replication used 2 pots - which are $22 \mathrm{~cm}$ (taller); $20 \mathrm{~cm}$ (bottom diameter); $29 \mathrm{~cm}$ (to diameter) - for each treatment and total 160 pots same with $1.68 \mathrm{~m}^{3}$ of soil. treatments.

\section{RESULTS AND DISCUSSION}

\section{Effect of weed densities on rice growth stage}

Table 1. The interaction between WD and V, which affect on plant height $(\mathrm{cm})$ at 72 DAP.

\begin{tabular}{|c|c|c|c|c|c|}
\hline \multirow{2}{*}{ Varieties rice } & \multicolumn{5}{|c|}{ Weed densities (per pot) } \\
\hline & Non - weed & One Weed & Two weeds & Three weeds & Four weeds \\
\hline OM 5451 & $88.66 \mathrm{abC}$ & $90.04 \mathrm{abC}$ & $83.54 \mathrm{bcC}$ & $87.38 \mathrm{abC}$ & $92.78 \mathrm{abC}$ \\
\hline OM 4900 & $102.71 \mathrm{Aa}$ & $102.86 \mathrm{Aa}$ & $94.66 \mathrm{Aab}$ & $100.93 \mathrm{Aab}$ & $102.91 \mathrm{Aa}$ \\
\hline Jasmine & 104.23 AaB & $99.19 \mathrm{abB}$ & $98.94 \mathrm{aBb}$ & $94.85 \mathrm{aBb}$ & $93.6 \mathrm{aBb}$ \\
\hline Cisokan & $96.89 \mathrm{AaBb}$ & $98.61 \mathrm{AaBb}$ & $91.88 \mathrm{AaBb}$ & $99.51 \mathrm{AaBb}$ & 87.69AaBb \\
\hline \multicolumn{3}{|l|}{ Sig } & \multicolumn{3}{|l|}{$\mathrm{ns}$} \\
\hline \multicolumn{3}{|l|}{$\mathrm{CV}$} & \multicolumn{3}{|l|}{7.1} \\
\hline \multicolumn{3}{|c|}{ Data collection and statistical analysis } & \multicolumn{3}{|c|}{ Impaction on height rice $(\mathrm{cm})$} \\
\hline \multicolumn{3}{|c|}{$\begin{array}{l}\text { By using Standard Evaluation System for Rice (SES) } \\
\text { from (Ampong-Nyarka \& S.K), the data of growth and } \\
\text { grain yield of rice were observed to tillering ability } \\
\text { (number of tiller), plant height }(\mathrm{cm}) \text {, leaf number, leaf } \\
\text { length }(\mathrm{cm}) \text { for vigor stage; beside it were observed to } \\
\text { grain yield of rice on panicles number, panicles length } \\
(\mathrm{cm}) \text {, filled grain, un-filled grain, W1000 (g) (per pot), } \\
\text { biomass (g). In addition, the data of this study were } \\
\text { taken every week in every pots into research and started } \\
\text { from the time rice had } 3 \text { leaves. For flowering time until } \\
\text { harvest, that time stopped taking data for make sure that } \\
\text { not have any destroy on yield by another factor without }\end{array}$} & \multicolumn{3}{|c|}{$\begin{array}{l}\text { Basing on data in Table } 1 \text {, increase WD did effect on } \\
\text { the height of rice } 72 \text { DAP, but it was not significant } \\
\text { (with } \mathrm{P}=0.271>0.05) \text {. As the result, weed is limited the } \\
\text { rice height at treatment } \mathrm{D} 1 \text { that mean in the small space } \\
\text { like pot. Weeds have stronger competitive with rice } \\
\text { about nutrient. Especially, there is nitrogen }\left(\mathrm{NO}_{3}{ }^{-} \text {) from }\right. \\
\text { soil and fertilizer; effective } \mathrm{N} \text { management aims to } \\
\text { increase rice ability to compete with weedy rice variants } \\
\text { (Olajumoke, Juraimi, Kamal, Husni, \& Alam, 2015) and } \\
\text { the research of (Awan, Chauhan, \& StaCruz, 2014) told } \\
\text { that high levels of } \mathrm{N} \text { fertilizer improved crop growth }\end{array}$} \\
\hline
\end{tabular}


and yield over weed. And more, the Table 1 show that the height of rice in V3 reduced following WD increased (from $104.23 \mathrm{~cm}$ to 93.6); however for the other varieties the height of rice increased in one weed treatment (D1) and reduce when increase more than two weed per pot. That's mean the competition of weed is not only negative impact on rice, it is also positive impact in rice growth with the appropriation of WD. Generally, the reduction in growth cause by competition for light which is considered also for some weed species; that did not have competition for light between weed and rice on changing height of tiller (Chauhan \& Johnson, Implication of Narrow Crop Row Spacing and Delayed Echinochloa colona and Echinochloa crus-galli Emergence for Weed Growth and Crop Yield, 2010); (Gibson \& Fischer, 2001).

On the other hands, with the difference in varieties have differently WD impact on HT of rice and it was significant different $(\mathrm{P}=0.000<0.05)$. Based on the data in Table 1, it is also show the best stable development of height rice is V3 (Jasmine) - which is D0V3 treatment $(104.23 \mathrm{~cm})$. In addition, the both D2V1 and D2V4 of variableness of height rice that showed $\mathrm{V} 1$ and $\mathrm{V} 4$ are sensitive with weed (Table 1); also showed that V2 is the best adaptation in condition of weed densities impact. However, it depends on the differential morphological characters of each varieties properties play a vital role in crop-weed competition (Namuco, Cairns, \& Johnson, 2009); (Ramesh \& Chauhan, 2016).

\section{Impaction on number of leaves of rice}

Following the data in Table 2, the interaction both of varieties and increasing in WD at 72 DAP was not significant different. However, it had different between D0 and D3 at treatments of V1 and V4 what the data showed NOL of these varieties at D3 better than D0 and also better than the others treatment of WD. In the fact, that beginning from $72 \mathrm{DAP}$ it is the early vigor stage of rice. In this stage, it does not have any growth of vegetative growth. Besides, the competition between weed and crop did not purely on NOL rice because competition for both nitrogen and light that happen strongest under condition of high fertility, competition for light was most important (Graf, Gutierrez, Rakotobe, Zahner, \& Delucchi, 1990). Summary, not have interaction between WD and number of leaf of varieties rice.

However, different varieties have varies of the number of leaves for each variety with significant different $(\mathrm{P}<0.05)$, it was showed in Table 2. The best one in V3; beside that the value of data from both of V1 and V4 is vary for each level of weed densities at 72 days ; it is also had the impact from the destroy tiller of larva Scirpohaga incertulas Walker from 51 DAP to 65 DAP. However, the competitive between weed - rice usually on light space and $\mathrm{CO}_{2}$ that stimulation rice increased number of leaf for growing in weedy condition. In the other hand, in the reported from (Caton, Foin, \& Hill, A Plant Growth Model for Integrated Weed Management in Direct - Seeded Rice. III., Interspecific Competition for Light. Field Crop Research 63 (1999)), the exception for a particular parameters and minor differences in phenology, weed growth processes are simulated exactly as for rice.

\section{Impaction on the number of tiller of rice}

As a result in Table 3, the more weed densities did not affect on number of tiller with non-significant $(\mathrm{P}>0.05)$ and it not had interaction between weed densities and varieties rice. The value of number tiller of rice are vary depend on each variety, which V1 and V4 showed the better growth of tiller in D3 treatment and V2 created more tiller in D2 treatment; however at V3 reduce the number of tiller following increased of WD. In there (Table 3), V1 and V4 is strongest of growth in competition of weed compete condition; so V3 was show how weed densities impact on growth at tiller stage. Thus, the number tiller efficiency is decided on the yield of rice.

Among these varieties, the development of tiller number was difference significant between four varieties with $\mathrm{P}<0.05$ in table 3; with the best rate at V3 (3.73 tiller). That show V3 is strong in ability of adaptation with environment condition in Indonesia.

Table 3. The interaction between WD and varieties of rice which affect on the number of tiller at 72 DAP

\begin{tabular}{|c|c|c|c|c|c|}
\hline \multirow{2}{*}{ Varieties } & \multicolumn{5}{|c|}{ Weed densities } \\
\hline & Non-weed & One weed & Two weeds & Three weeds & Four weeds \\
\hline OM 5451 & $2.88 \mathrm{aB}$ & $2.25 \mathrm{aB}$ & $2.5 \mathrm{AaB}$ & $3 \mathrm{Aa}$ & $2.63 \mathrm{AaB}$ \\
\hline OM 4900 & $2.63 \mathrm{AaB}$ & $3.38 \mathrm{AaB}$ & $3 \mathrm{AaB}$ & $3.25 \mathrm{AaB}$ & $3.13 \mathrm{AaB}$ \\
\hline Jasmine & $4.63 \mathrm{Aa}$ & $4.5 \mathrm{Aa}$ & $3.88 \mathrm{Aa}$ & $3.5 \mathrm{Aa}$ & $3.75 \mathrm{Aa}$ \\
\hline Cisokan & $3.5 \mathrm{Aa}$ & $3.5 \mathrm{Aa}$ & $3.63 \mathrm{Aa}$ & $4.5 \mathrm{Aa}$ & $3.5 \mathrm{Aa}$ \\
\hline Sig & ns & & & & \\
\hline $\mathrm{CV}$ & 35.6 & & & & \\
\hline
\end{tabular}


However, the best data of tiller number almost in D3 of each variety (Table 3); the same result from (Khan, Hasan, Anwar, \& Islam, 2017). The highest number of effective tillers hill ${ }^{-1}$ (10.48) was obtained from weed free treatment and the lowest one (4.36) in no weeding
On the other hand, look at Table 4, that show the growing of V3 and V2 is better than others varieties with significant $(\mathrm{P}<0.05)$. Following the research of (Juraimi, Uddin, Anwar, Mohamed , Ismail, \& Man, 2013), the effect of weeding regime on growth of rice

Table 4. The interaction effect WD and varieties on leaf length of rice at 72 DAP. Which is D0= non-weed, D1= one weed, D2= Two weeds, D3= three weeds, D4= four weeds.

\begin{tabular}{llllll}
\hline \multirow{2}{*}{ Varieties } & \multicolumn{5}{c}{ Weed densities per pot } \\
\cline { 2 - 6 } & Non-weed & One weed & Two weeds & Three weeds & Four weeds \\
\hline OM 5451 & $54.12 \mathrm{aB}$ & $55.99 \mathrm{aB}$ & $53.13 \mathrm{aB}$ & $53.93 \mathrm{aB}$ & $57.33 \mathrm{aB}$ \\
OM 4900 & $64.62 \mathrm{Aa}$ & $64.02 \mathrm{Aa}$ & $61.79 \mathrm{Aa}$ & $67.11 \mathrm{Aa}$ & $65.78 \mathrm{Aa}$ \\
Jasmine & $67.16 \mathrm{Aa}$ & $66.45 \mathrm{Aa}$ & $64.08 \mathrm{Aa}$ & $61.63 \mathrm{Aa}$ & $64.35 \mathrm{Aa}$ \\
Cisokan & $62.76 \mathrm{Aa}$ & $62.75 \mathrm{Aa}$ & $57.09 \mathrm{a}$ & $67.04 \mathrm{Aa}$ & $54.46 \mathrm{Aa}$ \\
\hline Sig & $\mathrm{ns}$ & & & \\
\hline CV $(\%)$ & 9.1 & & & \\
\hline
\end{tabular}

Note: $n$ s non-sidnificant of interaction between varieties rice and weed densities at meaning of 5\% $(P=0.868)$. Mean followed by a similar letter in a row are not significant different $(P=0.587>0.05)$ between five level of weed densities and A similar letter in the column A are significant different $(P=0.002<0.01)$ between four varieties rice.

treatment.

\section{Impaction on leaf length of rice}

As the result in Table 4, WD did not affect on leaf length at 72 DAP, with not significant and also not depends on many factors including growing season, competitiveness of variety, planting density, agronomic management and more factors from environment and also from research of (Namuco, Cairns, \& Johnson, 2009) told that different of cultivar rice their

Table 5. Interaction between weed densities and varieties rice show on the number of panicle of rice

\begin{tabular}{llllll}
\hline & \multicolumn{5}{c}{ Weed densities } \\
\cline { 2 - 5 } Varieties & Non-weed & One weed & Two weeds & Three weeds & Four weeds \\
& & & & \\
\hline OM 5451 & $3.01 \mathrm{abC}$ & $2.5 \mathrm{bC}$ & $3.25 \mathrm{abC}$ & $3.25 \mathrm{abC}$ & $2.75 \mathrm{bC}$ \\
OM 4900 & $3.5 \mathrm{aBbC}$ & $4.25 \mathrm{aBbC}$ & $3.5 \mathrm{aBbC}$ & $4.25 \mathrm{aBbC}$ & $3.75 \mathrm{aBbC}$ \\
Jasmine & $6.25 \mathrm{Aa}$ & $5 \mathrm{Aab}$ & $5 \mathrm{Aab}$ & $4.75 \mathrm{Aab}$ & $4.5 \mathrm{Aab}$ \\
Cisokan & $4.5 \mathrm{AaBb}$ & $5.25 \mathrm{AaBb}$ & $4.5 \mathrm{AaBb}$ & $5.5 \mathrm{AaBb}$ & $4.25 \mathrm{AaBb}$ \\
\hline Sig & $\mathrm{ns}$ & & & & \\
\hline $\mathrm{CV}$ & 31.4 & & & & \\
\hline
\end{tabular}

Note: $n$ s is non-significant at 5\% meaning for each harvest data of each variety. Mean followed by a similar letter in a row are not significant different $(P=0.844>0.05)$ between five level of weed densities and A similar letter in the column are significant different $(P=0.002<0.01)$ between four varieties rice.

interaction between WD and varieties showed on leaf length value. Besides that, the figure show that did not have any effect on leaf length by increasing WD during 72 DAP with non-significant $(\mathrm{P}>0.05)$. Based on the study from (Anwar, Juraimi, Samedani, Puteh, \& Man , 2012) tell that weeds do not compete with crops throughout the growing season. competitiveness with weeds have previously. In addition, the data that all of growth rate of leaf was obtained increase WD it is mean leaf length increase to compete about light and $\mathrm{CO}_{2}$ for photosynthesis (Potter \& Jones, 1977).

\section{Effect of weed densities on yield of rice}

\section{Panicle number per paddy}


Table 6. Interaction between weed densities and varieties rice show on the data of panicle length of rice

\begin{tabular}{llllll}
\hline & \multicolumn{5}{c}{ Weed densities } \\
\cline { 2 - 5 } Varieties & Non weed & One weed & Two weeds & Three weeds & Four weeds \\
\hline OM 5451 & $20.34 \mathrm{aBb}$ & $21.11 \mathrm{aBb}$ & $21.03 \mathrm{aBb}$ & $21.39 \mathrm{aBb}$ & $21.12 \mathrm{aBb}$ \\
OM 4900 & $22.84 \mathrm{Aab}$ & $23.5 \mathrm{Aa}$ & $23.03 \mathrm{Aab}$ & $23.45 \mathrm{Aab}$ & $23.15 \mathrm{Aab}$ \\
Jasmine & b & $24.43 \mathrm{Aab}$ & $24.41 \mathrm{Aab}$ & $24.65 \mathrm{Aa}$ & $24.23 \mathrm{Aab}$ \\
Cisokan & $19.47 \mathrm{Bb}$ & $21.45 \mathrm{aBb}$ & $19.93 \mathrm{aBb}$ & $22.66 \mathrm{aBb}$ & $20.26 \mathrm{aBb}$ \\
\hline Sig & & $\mathrm{ns}$ & & \\
\hline CV & 8.7 & & & \\
\hline
\end{tabular}

Note: $n$ s is non-significant at 5\% meaning for each harvest data of each variety. Mean followed by a similar letter in a row are not significant different $(P=0.9834>0.05)$ between five level of weed densities and A similar letter in the column are significant different $(P=0.002<0.01)$ between four varieties rice.

As the result show in Table 5, the fluctuation of panicle number appeared when weed densities change from D0 to $\mathrm{D} 4$; and the PN almost reduce follow WD increase. The sensitive one with WD is V3, the PN decrease from 6.25 (D0) to 4.25 (D4) that show weed completion results in economic yield losses (Anwar, Juraimi, Samedani, Puteh, \& Man , 2012) and in the fact of weed that the highest yield could be expected where crop plant densities and spatial uniformity were greater (Chauhan \& Johson, Growth Reponse of Direct Seeded Rice to Oxadiazon and Bispyribac-Sodium in Aerobic and Saturated Soils, 2011); (Ni, Moody, \& Robles, 2004); (Phuong, Denich, Vlek, \& Balasubramanian, varieties rice to WD competition. However, it was not significant different at $5 \%$ of meaning of statistics.

Among the varieties showed in Table 5, the number of panicle of each variety is significant different $(\mathrm{P}=0.000<0.01)$. The most amount of panicle at V3 panicle per rice bud and the lowest is V1 that show the effect of weeding regime on growth of rice depends on competitiveness of variety (Namuco, Cairns, \& Johnson, 2009); (Juraimi, Uddin, Anwar, Mohamed , Ismail, \& Man, 2013).

\section{Panicle length of rice}

As the result in Table 6, for each WD makes a change in

Table 7. The interaction of weed densities and varieties rice; also how weed densities affect on the total of Filled grain rice in different varieties.

\begin{tabular}{llllll}
\hline \multirow{2}{*}{ Varieties } & \multicolumn{5}{c}{ Weed densities } \\
\cline { 2 - 6 } & Non-weed & One weed & Two weeds & Three weeds & Four weeds \\
\hline OM 5451 & $289.03 \mathrm{aB}$ & $229.5 \mathrm{aB}$ & $241 \mathrm{aB}$ & $277 \mathrm{aB}$ & $264.5 \mathrm{aB}$ \\
OM 4900 & $383.5 \mathrm{Aa}$ & $477.75 \mathrm{Aa}$ & $433.75 \mathrm{Aa}$ & $434.5 \mathrm{Aa}$ & $472.5 \mathrm{Aa}$ \\
Jasmine & $620.5 \mathrm{Aa}$ & $487 \mathrm{Aa}$ & $474.5 \mathrm{Aa}$ & $453.5 \mathrm{Aa}$ & $438 \mathrm{Aa}$ \\
Cisokan & $451.75 \mathrm{Aa}$ & $486 \mathrm{Aa}$ & $439 \mathrm{Aa}$ & $416 \mathrm{Aa}$ & $425 \mathrm{Aa}$ \\
\hline
\end{tabular}

Sig ns

Note: $n$ s is non-significant at 5\% meaning for each harvest data of each variety. Mean followed by a similar letter in a row are not significant different $(P=0.968>0.05)$ between five level of weed densities and $A$ similar letter in the column are significant different $(P=0.00<0.01)$ between four varieties rice.

2005). Beside that, dependence on the adaptation ability which each variety rice that have varied in difference WD; the Figure 13 showed that. Summary, it is interaction of five level of WD and V3 showed in the figure which WD increasing made the number of panicle reduce; for other varieties it is not show the interaction between increased WD and reactive of the length of panicle but there it is not significant difference of interaction between the $\mathrm{WD}$ and $\mathrm{V}$ and also not interaction $(\mathrm{P}>0.05)$. However, increase WD is also increase panicle length of rice; the highest panicle length of D3V3 $(24.65 \mathrm{~cm})$ and the shortest is D0V4 $(19.47 \mathrm{~cm})$ (Table 6). In the research of AmpongNyarko and Datta (1991) showed weed infestations 
Table 8. The interaction of weed densities and varieties rice; also how weed densities affect on the total of UnFilled grain rice in different varieties.

\begin{tabular}{llllll}
\hline \multirow{2}{*}{ Varieties } & \multicolumn{5}{c}{ Weed densities } \\
\cline { 2 - 6 } & Non-weed & One weed & Two weeds & Three weeds & Four weeds \\
\hline OM 5451 & $35.96 \mathrm{ab}$ & $21.5 \mathrm{~b}$ & $22.5 \mathrm{~b}$ & $16.5 \mathrm{~b}$ & $25.75 \mathrm{~b}$ \\
OM 4900 & $112 \mathrm{ab}$ & $98.75 \mathrm{ab}$ & $103.25 \mathrm{ab}$ & $128.25 \mathrm{ab}$ & $84.75 \mathrm{ab}$ \\
Jasmine & $271.5 \mathrm{a}$ & $218.75 \mathrm{ab}$ & $205.5 \mathrm{ab}$ & $210.25 \mathrm{ab}$ & $240 \mathrm{ab}$ \\
Cisokan & $52 \mathrm{ab}$ & $105 \mathrm{ab}$ & $59 \mathrm{ab}$ & $223 \mathrm{ab}$ & $129.25 \mathrm{ab}$ \\
\hline Sig & $\mathrm{ns}$ & & & \\
\hline
\end{tabular}

Note: $n$ s is non-significant at 5\% meaning for each harvest data of each variety. Mean followed by a similar letter in a row are not significant different $(P=0.702>0.05)$ between five level of weed densities and A similar letter in the column are significant different $(P=0.00<0.01)$ between four varieties rice.

primarily constrain rice production by reducing grain yield. Yield reductions caused by uncontrolled weed growth throughout a crop season have been estimated to be from 44 to $96 \%$.

In addition, it also showed each variety was affected the WD and had the significant difference $(P=0.000)$ (Table 6). Particular, V3 is the highest of panicle length $24.3 \mathrm{~cm}$ and the shortest is V4 $20.76 \mathrm{~cm}$; different varieties rice is different on competitive ability with weed (Namuco, Cairns, \& Johnson, 2009); (Juraimi, Uddin, Anwar, Mohamed , Ismail, \& Man, 2013). and by causing lodging, removing all traces of the pigmented layer requires intense milling and results in decreased grain quality and lower milling rates (Ampong-Nyarko and De Datta, 1991).

Among these varieties rice had significant different $(\mathrm{P}=0.00<0.01)$ at filled and un-filled grain of rice; with the best one of filled grain is V3 and the lowest is V1; besides that the most of unfilled grain also is V3 and lowest is V1; following (Sunil, Shekara, Kalyanmurthy, \& Sha nkaralingapa, 2010) that season-long weed competition in rice may cause yield reduction up to $80 \%$

Table 9. The interaction of weed densities and varieties rice; also how weed densities affect on the W1000 (g) grain rice in different varieties.

\begin{tabular}{llllll}
\hline \multirow{2}{*}{ Varieties } & \multicolumn{5}{c}{ Weed densities } \\
\cline { 2 - 5 } & Non-weed & One weed & Two weeds & Three weeds & Four weeds \\
\hline V1 & $24.52 \mathrm{e}-\mathrm{i}$ & $25.19 \mathrm{afgh}$ & $25.57 \mathrm{def}$ & $25.35 \mathrm{efg}$ & $25.54 \mathrm{def}$ \\
V2 & $27.59 \mathrm{a}-\mathrm{e}$ & $27.21 \mathrm{a}-\mathrm{e}$ & $26.68 \mathrm{cde}$ & $27.09 \mathrm{bcd}$ & $26.93 \mathrm{bcde}$ \\
V3 & $30.69 \mathrm{a}$ & $30.29 \mathrm{ab}$ & $30.71 \mathrm{a}$ & $29.87 \mathrm{abc}$ & $28.96 \mathrm{abc}$ \\
V4 & $23.02 \mathrm{fghi}$ & $21.78 \mathrm{hij}$ & $21.89 \mathrm{ghij}$ & $20.9 \mathrm{ij}$ & $19.26 \mathrm{ij}$ \\
\hline Sig & $\mathrm{ns}$ & & & & \\
\hline
\end{tabular}

Note: $n s$ is non-significant at 5\% meaning for each harvest data of each variety. Mean followed by a similar letter in a $r$ ow are not significant different $(P=0.259>0.05)$ between five level of weed densities and A similar letter in the column are significant different $(P=0.00<0.01)$ between four varieties rice.

\section{Filled and un-filled grain}

Table 7 show that the number of unfilled grain and filled grain of rice is change - increased for unfilled grain and decrease for filled grain - when the WD increased, but not significant different (Table 7). The most of filled grain is D0V3 (620.5); which treatment D0V3 also is the most unfilled-grain, because of the attack from pets during the maturity stage of rice; weeds hamper rice harvesting and increase harvest costs through direct interference with the harvesting operation and complete failure of crops due to weeds in rice (Jayadeva, et al., 2011).

\section{Impaction of weed densities on $\mathrm{W1000}(\mathrm{g})$ of rice}

The interaction of WD and V is not significant different about the both of $\mathrm{W} 1000$ of rice grain $(\mathrm{P}=0.259>0.05)$. However, at Table 9, increasing WD is also decrease W1000, with V3 is the best one. And decreases occurred when the Ludwigia plant density beyond 2 plants $/ \mathrm{m}^{2}$ (Dharmaratne \& Ranamukaarachchi, 1991). 
The reason that rice yield losses from water deficit depend on the severity and duration of the deficit, the maturity is the stage that rice in drought condition; rice and weeds differ in their tolerance for drought because of differences in their root distribution, root elongation rate, genetic tolerance for low water availability in plant tissue, and control of water loss through transpiration. $\mathrm{C}_{4}$ weeds have lower water requirements than those of $\mathrm{C}_{3}$ rice and are able to tolerate more drought stress than rice (Ampong-Nyarko and De Datta, 1991). However, the yield loss is also depend on many factors include the densities of weed, such as weed ecotype; the emergence time (weed and rice); rainfall in the paddy field; temperature (Renton and Chauhan, 2017; Zimdahl 2004).

Table 10. The interaction of weed densities and varieties rice; also how weed densities affect on the Biomass (g) data in different varieties

\begin{tabular}{lll}
\hline Treatments & Wfr $(\mathrm{g})$ & Wdr $(\mathrm{g})$ \\
\hline D0V1 & $37.44 \mathrm{a}$ & $7.48 \mathrm{bCc}$ \\
D0V2 & $53.20 \mathrm{a}$ & $12.19 \mathrm{aBbc}$ \\
D0V3 & $62.46 \mathrm{a}$ & $15.98 \mathrm{Aa}$ \\
D0V4 & $51.78 \mathrm{a}$ & $10.43 \mathrm{aBbCc}$ \\
D1V1 & $34.76 \mathrm{a}$ & $6.83 \mathrm{Cc}$ \\
D1V2 & $57.38 \mathrm{a}$ & $12.61 \mathrm{aBbc}$ \\
D1B3 & $61.28 \mathrm{a}$ & $15.11 \mathrm{Aab}$ \\
D1V4 & $38.73 \mathrm{a}$ & $8.77 \mathrm{aBbCc}$ \\
D2V1 & $34.87 \mathrm{a}$ & $7.54 \mathrm{bCc}$ \\
D2V2 & $43.52 \mathrm{a}$ & $10 \mathrm{aBbc}$ \\
D2V3 & $58.38 \mathrm{a}$ & $14.41 \mathrm{Aabc}$ \\
D2V4 & $38.59 \mathrm{a}$ & $8.82 \mathrm{aBbCc}$ \\
D3V1 & $39.02 \mathrm{a}$ & $8.48 \mathrm{abCc}$ \\
D3V2 & $44.7 \mathrm{a}$ & $10.72 \mathrm{aBbc}$ \\
& $48.74 \mathrm{a}$ & $12.52 \mathrm{Aabc}$ \\
\hline & 535 &
\end{tabular}

ItL3 Vht have interact not significant different showed on the value of biomass (the ${ }^{4}$ fresh and dry $40.44 \mathrm{w}$ ight $) \quad\left(\mathrm{P}_{\mathrm{Wfr}}=8.353 \mathrm{apCc}>0.05\right.$; $\left.\mathrm{P}_{\text {Y } 4}=\overline{\mathrm{V}} 0.510>0.05\right)$. The Table 10 shows the value of D0V 3 is the heaviest one $(62.46 \mathrm{~g}$ of Wfr, $15.98 \mathrm{~g}$ of

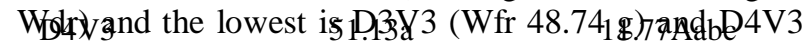
(Wdr $11.77 \mathrm{~g}$ ). In general, rice dry matter yield were be redetded by $1 \mathrm{~kg}$ for eterzakilogram of weedsberduced in the same area (Kweel Ampong-Nyarko and De Datta, 19d9). Following Dhasmaratne and Randsmukaarchchi
(1991), dry weight of rice decreased (from 2,762 to $2,342 \mathrm{~kg} / \mathrm{ha}$ ), but the difference was not significant during mature; the decrease in rice dry matter could be due to the reduction in the LAI (leaf area index) and tiller number as a response to competition by Ludwigia. In addition, the data of Wfr and Wdr from V1 were the lowest data; the data of Wfr of rice (V1) increasing with increasing on WD (from D0 to D4 weedy per pot); it changes from $37.44 \mathrm{~g}$ to $40.44 \mathrm{~g}$ in the Table 10.

Nevertheless, different Wfr, Wdr have vary of data, it decreased form non-weedy $(7.84 \mathrm{~g})$ to one weedy $(6.83$ $\mathrm{g}$ ), after that increasing from $6.83 \mathrm{~g}$ (D1V1) to $8.82 \mathrm{~g}$ (D3V1) and decreased at D4V1 (8.35 g) (Table 10 and $11)$.

\section{CONCLUSIONS}

The study was investigative the effect of weed densities on growth and yield of introduce several Vietnam varieties rice with the condition in Padang. The result of study explained that and also not interaction between WD and varieties showed on growth stage of rice (tiller height, number of tiller, number of leaf). However, on data of leaf length at 58 DAP showed significant difference $(\mathrm{P}=0.017)$; all of growth rate of leaf was obtained increase WD it is mean leaf length increase to compete about light and $\mathrm{CO}_{2}$ for photosynthesis. Beside the growth of rice, harvest data also are not significant different of statistical in interactive between WD and varieties rice, but it has different in data. In short, V3 showed the best data of harvest and medium of growth data. In addition, the study explain in each treatment of weed not impact on growth stage of rice; but it is have an impact on harvest value (W1000, FG, UFG), due to increasing WD (non - weed to four weeds per pot) the yield of rice reducing too which D2 and D4 are more effective on growth and yield of rice, however it was non - significant. All the measurements of harvest showed significant differences among groups of varieties rice, while variation due to interaction between WD and variety was not significant. And it is same case for the measurement about growth rate of interaction between WD and varieties rice in the study. The extent of crop loss caused by weeds depends on several factors that include species of weeds present, density of weeds and crop, duration of weed-crop association, and growth and distribution of weeds.

\section{References}

Ampong-Nyarka, K., \& S.K, D. D. (t.thn.). A Handbook For Weed Conttrol In Rice IRRI. 1991.

Anwar, M. P., Juraimi, A. S., Samedani, B., Puteh, A., \& Man , A. (2012). Critical Period of Weed Control in Aerobic Rice The Scientific World J. 1-10. 
Awan, T. H., Chauhan, B. S., \& StaCruz, P. C. (2014). Physiological and Morphological Responese of Ischaemum rugosum Saliisb (Wrinkled grass) to Different Nitrogen Rates and Rice Seeding Rates. PloS One 9 (6) e98255.

Cabi, Invasive Species Compendium. (2019). Ludwigia Ocrovalvis (Primrose Willow).

Caton, B. P., Foin, T. C., \& Hill, J. E. (Interspecific Competition for Light. Field Crop Research 63 (1999)). A Plant Growth Model for Integrated Weed Management in Direct - Seeded Rice. III. $1999,47-61$.

Caton, B. P., Mortimer, M., Hill, J. E., \& Johnson, D. E. (2010). Book : A Partical Field Guide to Weeds of Rice in Asia. Los Banos Laguna Philippines: IRR- International Rice Research Institute.

Chauhan, B. S., \& Johnson, D. E. (2010). Implication of Narrow Crop Row Spacing and Delayed Echinochloa colona and Echinochloa crus-galli Emergence for Weed Growth and Crop Yield. Field Crop Research 117 (2010), 177-182.

Chauhan, B. S., \& Johson, D. E. (2011). Growth Reponse of Direct Seeded Rice to Oxadiazon and Bispyribac-Sodium in Aerobic and Saturated Soils. Weed SCI 59, 119-122.

Chauhan, B. S., Jabran, K., \& Mahajan, G. (2017). Rice Production Worldwide. Switzerland: Springer International Publishing AG.

Dharmaratne, P. G., \& Ranamukaarachchi, S. L. (1991). Sensitivity of Rice to Ludwigia decurrens (L). Tropical Agricultural Research.

Food and Agriculture Origanization of The United Nations (FAO). (2018). Rice Market Monitor.

Ghersa, C. M., Benech-Arnold, R. L., Satorre, E. H., \& Martinez-Ghersa, M. A. (2000). Advances in Weed Management Strategies. Field Crops Res, 67, 95-104.

Gibson, K. D., \& Fischer, A. J. (2001). Relativr Growth and Photosynthetic Response of Water Seeded Rice and Echinoloa oryzoides. International Journal Pest Management 47, $305-309$.
Graf, B., Gutierrez, A. P., Rakotobe, O., Zahner, P., \& Delucchi, V. (1990). A Similation Model for The Dynamics of Rice Growth and Development: II. The Competition with Weeds for Nitrogen and Light. Agricuturel Syst 32, $367-392$.

Jayadeva, H. M., Bhairappanavar, S. T., Hugar, A. Y., Rangaswamy, B. R., Mallikarjun, G. B., Malleshappa, C., et al. (2011). Integrated Weed management in Aerobic Rice ( Oryza sativa L.). Agril Sci Digest, 58-61.

Juraimi, A. S., Uddin, M. K., Anwar, M. P., Mohamed , M. T., Ismail, M. R., \& Man, A. (2013). Sustainable Weed Management in Direct Seeded Rice Culture: A Review. Australian J Crop Sci, 7(7), 989-1002.

Khan, M. Z., Hasan, A. K., Anwar, M. P., \& Islam, M. S. (2017). Weeding Regime and Plant Spacing Influence on Weed Growth and Performance of Transplant Aman Rice Variety Binadhan- 7. Fundamental and Applied Agricilture Joural.

Naidu, V. S. (2012). Hand Book on Weed Identification. Directorate of Weed Science Research, 354.

Namuco, O. S., Cairns, J. E., \& Johnson, D. E. (2009). Investigating Early Vigour in Upland Rice (Oryza sativa L.): Part I. Seedling Growth and Grain Yield in Competition with Weeds. Field Crop Research 113 (2000), 197 - 206.

Ni, H. W., Moody, K., \& Robles, R. P. (2004). Analysis of Competition Between Wet-Seeded Rice and Baryardgrass (Echinocholoa crus-galli) Using A Response-Surface Model. Weed Sci. 52, 142146.

Oerke, E. C., \& Dehne, H. W. (2004). Safeguarding Production- Losses in Major Crops and The Role of Crop Protection. Crop Production, 275-285.

Olajumoke, B., Juraimi, A. S., Kamal, Husni, M. H., \& Alam, A. (2015). Competitive ability of cultivated rice against weedy rice biotypes - A review. Chileen Journal of Agricultural Research. 
Phuong, L. T., Denich, M., Vlek, P. L., \& Balasubramanian, V. (2005). Suppressing Weeds in Direct-Seeded Lowland Rice: Effect of Methods and Rates of Seeding. J. Agron. Crop Sci. 191, 185-235.

Potter, J. R., \& Jones, J. W. (1977). Leaf Area Partitioning as An Important Factor in Growth. Plant Physiol.

Quang , H. (2017). The Year of Rice in Viet Nam, 2017s.

Ramesh, A. K., \& Chauha, B. S. (2016). Role of Crop Competition in Managing Weeds in Rice, Wheat and Maize in India. Crop Protection 95 (2017), 14-21.

Ramzan, M. (2003). Evaluation of Various Planting Methods in Rice-Wheat Cropping Systems, Punjab, Pakistan. Rice Crop Report.

Sunil, C. M., Shekara, B. G., Kalyanmurthy, K. N., \& Sha nkaralingapa, B. C. (2010). Growth and Yield of Aerobic Rice as Influenced by Integrated Weed Management Practices. Indian J Weed Sci, 180-183. 